\title{
41AN28: An Ancestral Caddo Settlement on Mound Prairie Creek in the Neches River Basin in East Texas
}

Timothy K. Perttula

Heritage Research Center, Stephen F. Austin State University

Follow this and additional works at: https://scholarworks.sfasu.edu/ita

Part of the American Material Culture Commons, Archaeological Anthropology Commons, Environmental Studies Commons, Other American Studies Commons, Other Arts and Humanities Commons, Other History of Art, Architecture, and Archaeology Commons, and the United States History Commons

Tell us how this article helped you.

This Article is brought to you for free and open access by the Center for Regional Heritage Research at SFA ScholarWorks. It has been accepted for inclusion in Index of Texas Archaeology: Open Access Gray Literature from the Lone Star State by an authorized editor of SFA ScholarWorks. For more information, please contact cdsscholarworks@sfasu.edu. 


\section{AN28: An Ancestral Caddo Settlement on Mound Prairie Creek in the Neches River Basin in East Texas \\ Creative Commons License \\ (c) (1) (9)}

This work is licensed under a Creative Commons Attribution-NonCommercial 4.0 International License 


\title{
41AN28: An Ancestral Caddo Settlement on Mound Prairie Creek in the Neches River Basin in East Texas
}

\author{
Timothy K. Perttula
}

\section{INTRODUCTION}

Site 41AN28 is an extensive ancestral Caddo settlement on an alluvial terrace on the west side of Mound Prairie Creek in the Post Oak Savannah of East Texas (Figure 1). Mound Prairie Creek is an southward- and eastward-flowing tributary to the Neches River. The confluence of the two streams lies about $20 \mathrm{~km}$ to the east.

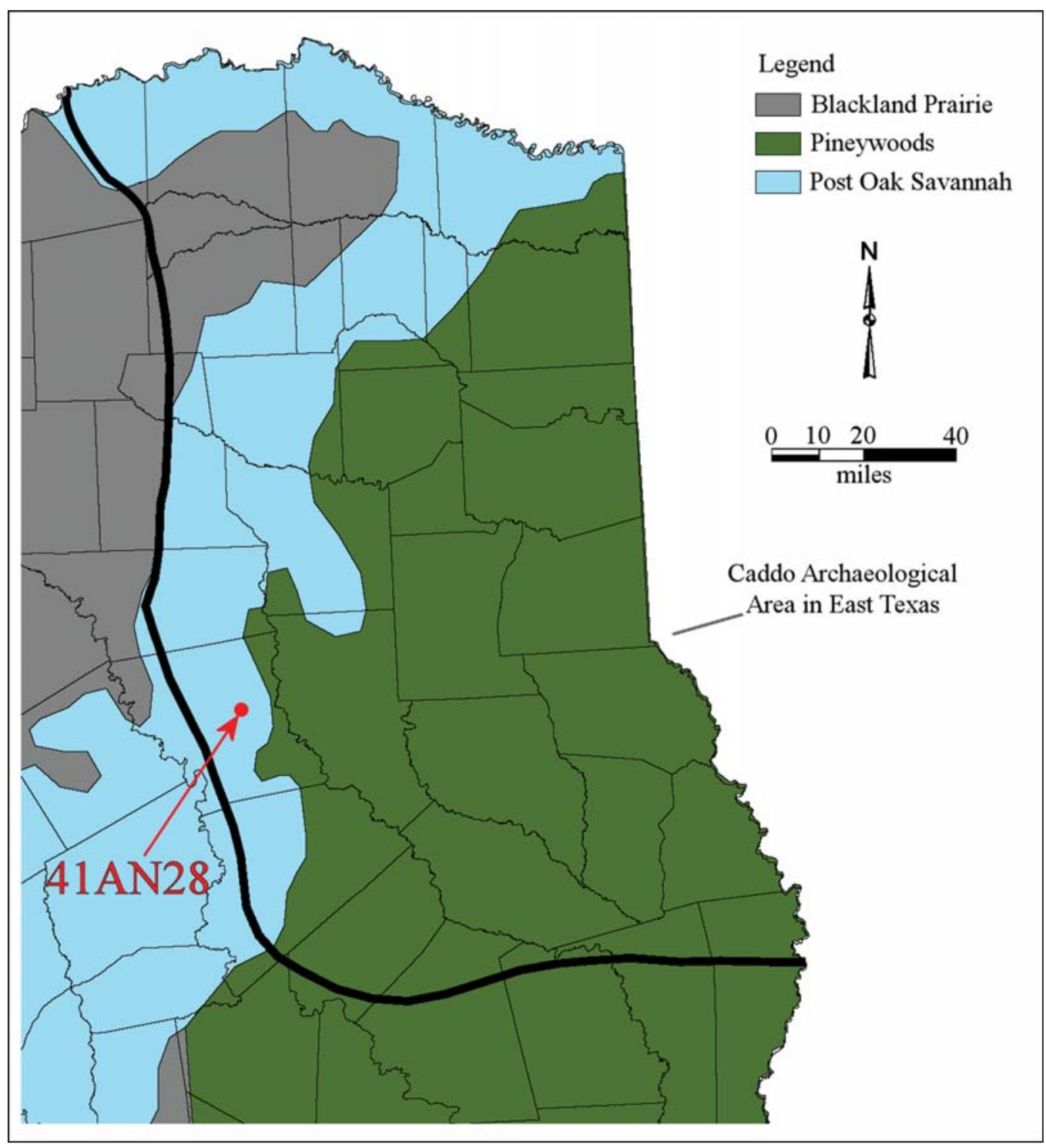

Figure 1. The location of 41AN28 in East Texas. 
Directly to the east of 41AN28 on the east side of Mound Prairie Creek lies the Pace McDonald site (41AN51). This site is an important Middle Caddo period (ca. A.D. 1200-1400) mound center with at least two earthen mounds and a settlement that covers more than 11 acres (Perttula et al. 2012:78). Both investigated mounds at Pace McDonald were built to cover and bury special purpose structures where significant deposits of ash were accumulated, probably ash temples like those uncovered in the main mound at the nearby A. C. Saunders site (41AN19). Two calibrated radiocarbon dates from habitation areas at the Pace McDonald site range from A.D. 1200-1410 (Perttula et al. 2012:54).

\section{SITE INVESTIGATIONS}

Clyde Amick, an avocational archaeologist from Palestine, Texas, found and investigated 41AN28 between 1983-1985. He donated much of his collection (retaining projectile points and ground stone tools) from the site to the Texas Archeological Research Laboratory at The University of Texas at Austin (TARL) in October 1985. The work done by Amick consisted of surface collections in three plowed fields that stretched for ca. $1 \mathrm{~km}$ west of Mound Prairie Creek (Figure 2), and the excavation of 21 test pits of various sizes in a midden deposit near the northern end of 41AN28.

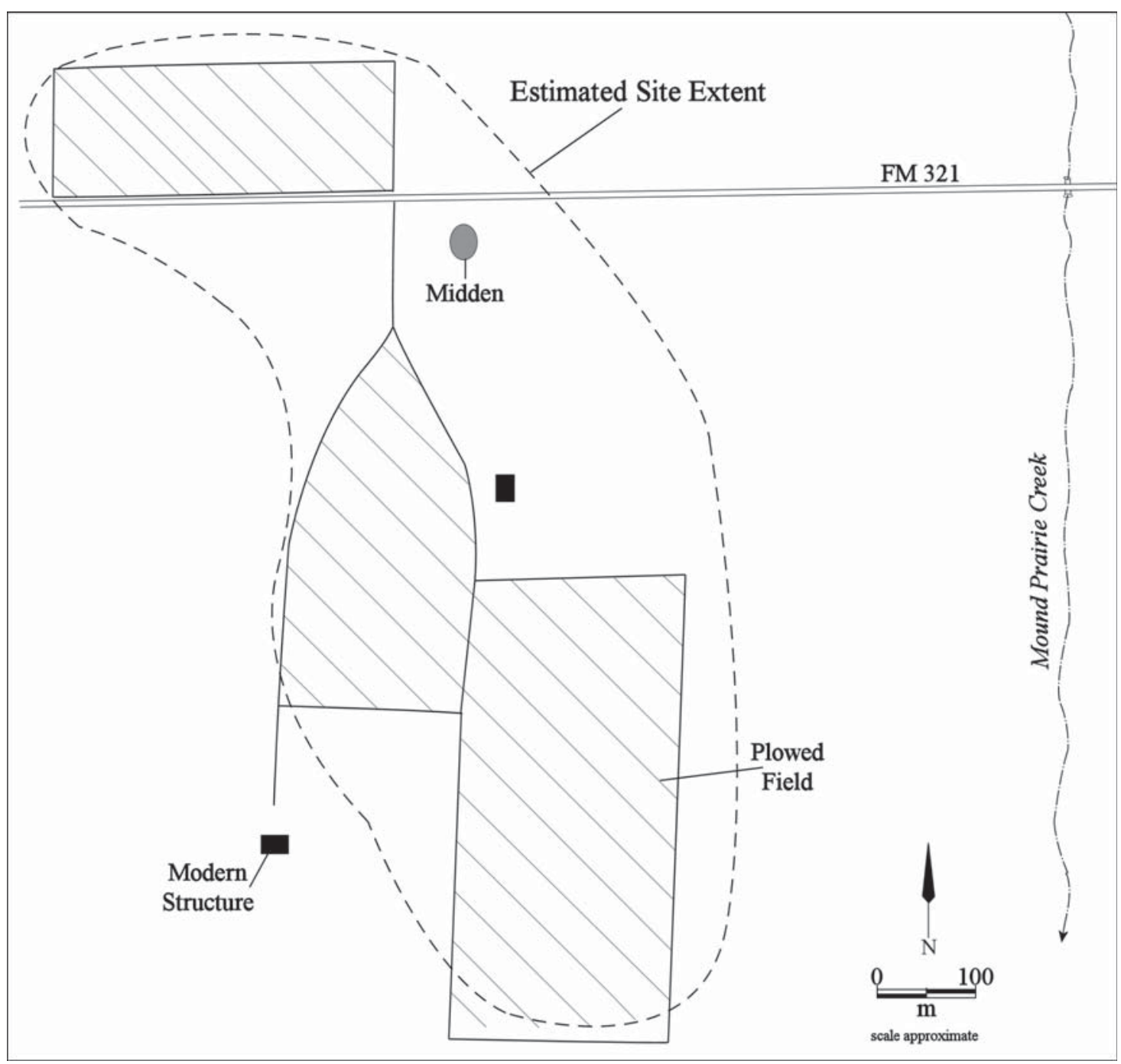

Figure 2. Plowed field surface collection areas and midden feature at 41AN28 on Mound Prairie Creek. 
The dimensions of the midden deposits are not known, but they were described by Amick as a maximum of ca. $61 \mathrm{~cm}$ in depth. The midden had areas with black sandy loam mixed with pieces of charcoal. The 21 test pits ranged from as small as $0.5 \times 0.6 \mathrm{~m}$ to as large as $0.6 \times 1.8 \mathrm{~m}$ in size, with an estimated total area excavated in the midden of ca. $11.7 \mathrm{~m}^{2}$.

\section{ARTIFACT ASSEMBLAGE}

The TARL collections from 41AN28 are from various surface collection areas in the plowed fields, with none from any of the midden test pits. These collections primarily consist of ceramic sherds from plain ware, utility ware, and fine ware vessels.

\section{Chipped Stone Tools}

Personnel from TARL examined the projectile points from 41AN28 recovered by Amick in surface collections as well as his midden excavations, and Amick prepared notes concerning the various ground stone tools recovered in his investigations. In addition to several chipped stone drills, there were large numbers of both dart points $(n=125)$ and arrow points $(n=37)$ found at the site (Table 1).

Table 1. Projectile points from 41AN28 in the Amick collection.

\begin{tabular}{|c|c|c|c|c|c|}
\hline Type & $\begin{array}{c}\text { Surface Coll. } \\
\text { No. }\end{array}$ & Percent & $\begin{array}{l}\text { Midden } \\
\text { No. }\end{array}$ & Percent & Sum \\
\hline
\end{tabular}

\section{Dart point}

Bulverde

Calf Creek

Dawson

Edgewood

Gary

Late Paleoindian

Yarbrough

Untyped Late Archaic

Untyped Middle Archaic

Unidentified fragments

Subtotal

$\begin{array}{rr}3 & 2.6 \\ 1 & 0.9 \\ 7 & 6.0 \\ 1 & 0.9 \\ 28 & 24.1 \\ 2 & 1.7 \\ 2 & 1.7 \\ 41 & 35.3 \\ 3 & 2.6 \\ 28 & 24.1 \\ 116 & 100.0\end{array}$

0.9

6.0

0.9

4.1

1.7

35.3

100.0

$\begin{array}{lcr}- & - & 3 \\ - & - & 1 \\ - & - & 7 \\ - & - & 1 \\ 2 & 22.2 & 30 \\ - & - & 2 \\ 1 & 11.1 & 3 \\ - & - & 41 \\ - & - & 3 \\ 6 & 66.7 & 34 \\ 9 & 100.0 & 125\end{array}$

\section{Arrow point}

\begin{tabular}{lccccr} 
Expanding stem & 8 & 36.3 & 4 & 26.7 & 12 \\
Friley & - & - & 1 & 6.7 & 1 \\
Perdiz & 3 & 13.6 & 3 & 20.0 & 6 \\
Steiner & - & - & 3 & 20.0 & 3 \\
Straight stem & 7 & 31.8 & - & - & 7 \\
Unidentified fragments & 4 & 18.2 & 4 & 26.7 & 8 \\
Subtotal & 22 & 100.0 & 15 & 100.0 & 37 \\
\hline Totals & 138 & 24 & & 162 \\
\hline
\end{tabular}


The different dart points from 41AN28 include two Late Paleoindian (ca. 10,000 years B.P.) lanceolate specimens with straight but beveled stems, lateral grinding, flat bases, and resharpened blades (see Table 1). The remainder of the dart points span the period from ca. 8000-1250 years B.P. (Middle Archaic to the Woodland periods), with most of the points indicative of Late Archaic (ca. 5000-2500 years B.P.) and Woodland period (ca. 2500-1250 years B.P.) use by aboriginal groups living in East Texas.

The arrow points are also diverse from 41AN28 (see Table 1). The represented types suggest the site was occupied by groups that used the first arrow points in the region-i.e., Friley and Steiner (see Shafer and Walters 2010) around A.D. 700-800 - to Caddo groups that lived at the site after ca. A.D. 1250 and made Perdiz arrow points. The straight stem arrow points may be ca. A.D. 1000-1300 Alba points (Turner et al. 2011:177).

\section{Ground Stone Tools}

Ground stone tools were relatively abundant at 41AN28. Amick identified manos, mano/pitted stones, pitted stone (with single as well as multiple pits), grinding slabs, and abraders. These tools were made from local ferruginous sandstone.

\section{Woodland Period Ceramic Sherds}

A small assemblage of Woodland period sandy paste ceramic sherds are in the 41AN28 collections. These sherds include five plain rim sherds and 18 plain body sherds from Goose Creek Plain, var. unspecified vessels. This ceramic ware is associated with Woodland period cultures in the southern part of East Texas, and is evidence that the site was first occupied sometime during the Woodland period, between ca. 500 B.C. and A.D. 800 (see Ellis 2013; Perttula 2013).

There are also three decorated sandy paste sherds in the 41AN28 assemblage. One is a rim with a single horizontal incised line, another is a body sherd with a broad U-shaped horizontal incised line (cf. Marksville Incised, var. unspecified), and a rim with lip notching. If the body sherd with a broad U-shaped incised line is related culturally or temporally to Marksville Incised, this would suggest one aboriginal occupation of the site between ca. 100 B.C. and A.D. 300.

\section{Caddo Ceramic Vessel Sherds}

The assemblage of Caddo ceramic sherds from 41AN28 totals 1725 rim, body, and base sherds (Table 2). Most of the sherds are undecorated, and the plain to undecorated sherd ratio is 2.56 . Based on the rims from the three wares $(n=62)$, more than half the vessels are from utility wares $(n=33,53$ percent $)$, followed by plain jars and bowls ( $\mathrm{n}=19,31$ percent), and much lesser amounts of fine wares ( $\mathrm{n}=10,16$ percent).

Table 2. Caddo Ceramic Sherds from 41AN28.

\begin{tabular}{lrrrr}
\hline Ware & Grog & Bone & N & Percent \\
\hline Plain & 1141 & 100 & 1241 & 71.9 \\
Utility & 372 & 42 & 414 & 24.0 \\
Fine & 66 & 4 & 70 & 4.1 \\
\hline Totals & 1579 & 146 & 1725 & 100.0 \\
\hline
\end{tabular}


More than 91 percent of the sherds from the three wares are from grog-tempered vessels, and approximately 8.5 percent are from bone-tempered vessels. The lowest proportion of bone-tempered vessels are in the fine wares $(5.7$ percent), followed by the plain wares ( 8.0 percent); 10.1 percent of the sherds from utility ware vessels are bone-tempered (see Table 2).

Sherds from utility ware vessels comprise more than 85 percent of the decorated sherd sample $(n=484)$. Approximately 57 percent of the decorated sherds, but only 12 percent of the utility ware rims, have brushed decorations (Table 3); this suggests many utility ware vessels have brushed decorations only on their vessel bodies, and another decorative method on the vessel rim. Another 1.7 percent of the utility ware sherds have brushed decorations in combination with other decorative elements (i.e., incised, incised-punctated, and punctated). Sherds from incised vessels represent 21 percent of the utility ware sherds and 52 percent of the utility ware rims, indicating that incised vessels are quite common in the 41AN28 utility ware sherds. Sherds with punctated decorations account for 13 percent of the utility ware sherds as well as 18 percent of the rim sherds, while incised-punctated sherds comprise 6 percent of all the utility ware sherds and 12 percent of the utility ware rim sherds (Table 3); these decorative methods are equally likely to occur on the rim as on the body of these utility wares.

Table 3. Decorative methods and elements in the utility ware sherds from 41AN28.

\begin{tabular}{lll}
\hline $\begin{array}{l}\text { Decorative method/ } \\
\text { Decorative element }\end{array}$ & Rim & Body
\end{tabular}

Decorative element

\section{Appliqued}

straight appliqued ridge

\section{Brushed}

horizontal brushing marks

opposed brushing marks

overlapping brushing marks

parallel brushing marks

vertical brushing marks

\section{Brushed-Incised}

horizontal and vertical lines; diagonal brushed body

parallel brushed-incised

\section{Brushed-Incised-Punctated}

circular punctated row above horizontal incised line; vertical brushed body

diagonal opposed lines, diagonal

brushing marks and circular punctate row

\section{Brushed-Punctated}

parallel brushed and adjacent tool

punctated row

$\mathrm{N}$

$-$

1

2

2

$-$

$-$

$-$

2
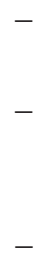

1

1

1

3

1

228

2

1

3

(1)

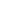

Nons 
Table 3. Decorative methods and elements in the utility ware sherds from 41AN28, cont.

\begin{tabular}{lll}
\hline $\begin{array}{l}\text { Decorative method/ } \\
\text { Decorative element }\end{array}$ & Rim & Body
\end{tabular}

\section{Incised}

cross-hatched lines

curvilinear lines

diagonal lines, L-R

diagonal lines, $\mathrm{R}-\mathrm{L}$

diagonal opposed lines

horizontal lines

horizontal-diagonal lines

opposed lines

parallel lines

straight line

triangle element

vertical lines

vertical and diagonal (R-L)

2
1
3
6
-
1
-
-
-
-
-
3
1

11

$\begin{array}{ll}- & 1\end{array}$

$\begin{array}{ll}- & 3\end{array}$

$\begin{array}{ll}- & 6\end{array}$

$5-5$

$\begin{array}{ll}- & 1\end{array}$

1

$11-11$

$23-23$

$19 \square$

$1+1$

$\begin{array}{ll}- & 3 \\ - & \end{array}$

1

Incised-Appliqued

diagonal lines (L-R) and vertical

1

appliqued ridge

Incised-Punctated

curvilinear lines and tool punctated zones

$-$

2

filled triangle

diagonal opposed lines and triangle with

tool punctates

incised triangle filled with tool punctates

parallel lines and adjacent circular

punctated zone

parallel lines and adjacent tool punctated zone

parallel lines with linear tool punctated

row between incised lines

straight line and adjacent tool punctated zone

Lip Notched

Punctated

cane punctated rows

circular punctated rows

fingernail punctated rows

linear tool punctated rows

tool punctated rows

tool punctated, horizontal-diagonal rows

Totals

33

\begin{tabular}{lrr}
- & 1 & 1 \\
- & 4 & 4 \\
1 & 13 & 14 \\
- & 2 & 2 \\
5 & 28 & 33 \\
- & 1 & 1 \\
\hline
\end{tabular}

381

414

$\mathrm{L}-\mathrm{R}=$ left to right; incised lines begin at the left at the top of the rim and end at the right at the bottom of the rim; $\mathrm{R}-\mathrm{L}=$ right to left; incised lines begin at the right at the top of the rim and end at the left at the bottom of the rim 
The one appliqued body sherd has a straight appliqued ridge that likely divided the body of a vessel into plain panels. Such vertical appliqued ridges are found on La Rue Neck Banded jars (Suhm and Jelks 1962:93). The many brushed, parallel brushed-incised, and brushed-punctated rim and body sherds are from Bullard Brushed jars. They have horizontal and vertical brushing marks on vessel rims as well as vertical brushing marks on the vessel body. Untyped brushed utility ware sherds include one brushed-incised sherd with vertical and horizontal incised lines on the lower rim as well as diagonal brushing marks on the vessel body (Figure 3d), as well as brushed-incised-punctated sherds. These have single rows of circular punctates, either in a row above a single horizontal line at the rim-body junction and vertical brushing on the vessel body (Figure 3e), or in a diagonal row pushed through diagonal brushing marks adjacent to diagonal opposed incised lines.

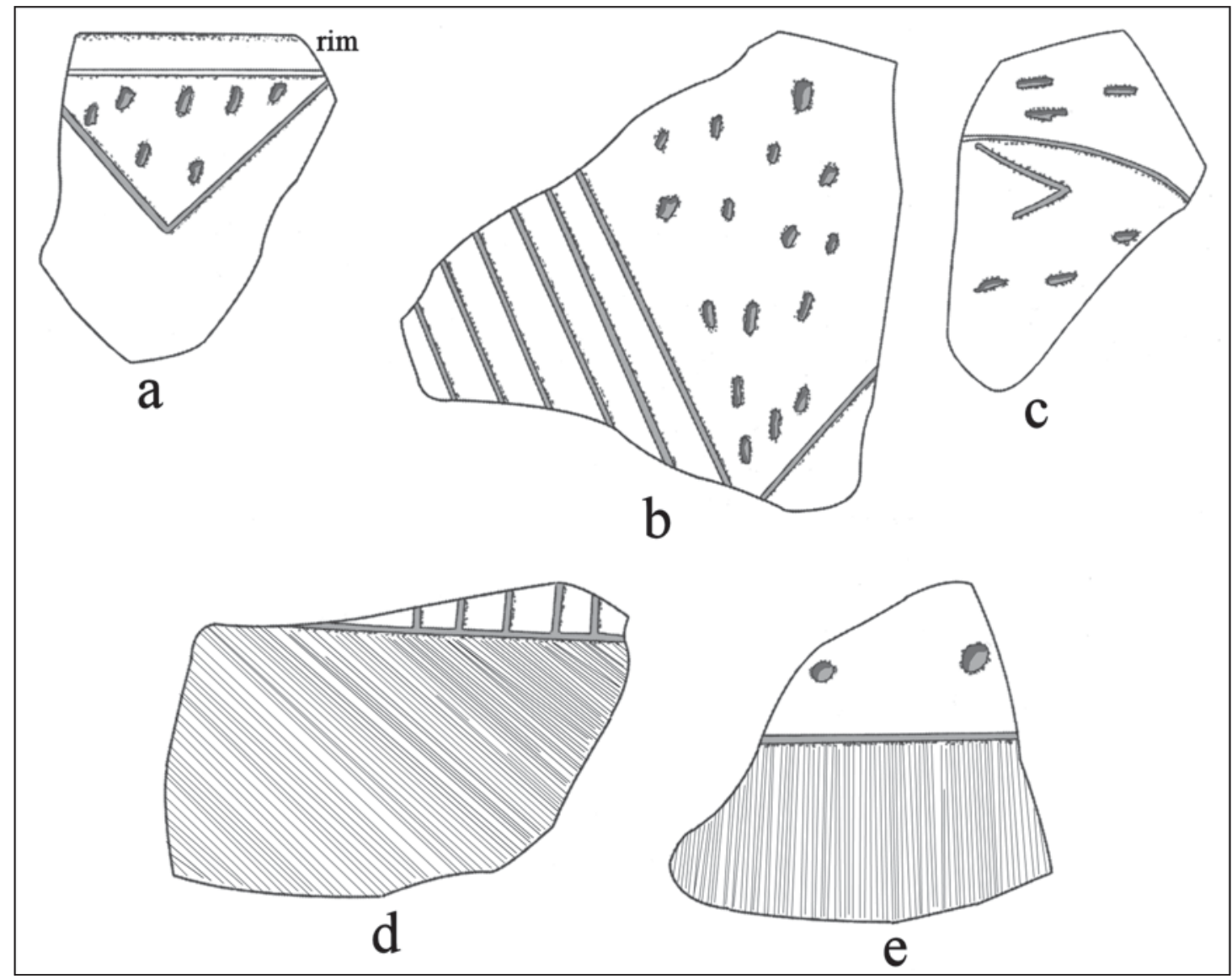

Figure 3. Selected decorative elements on utility ware sherds from 41AN28: a-c, incised-punctated; $\mathrm{d}$, brushed-incised; e, incised-punctated-brushed.

The incised and incised-punctated rim and body sherds from 41AN28 are most likely all from Maydelle Incised jars, except for the one horizontal incised rim (see Table 3). These vessels either have cross-hatched, curvilinear, diagonal, vertical, or vertical-diagonal incised lines on the rim, or diagonal and diagonal opposed incised lines forming triangles or zones filled with tool punctations (see Figure 3a-c). One unique incisedappliqued rim sherd, possibly from a local variety of Maydelle Incised, in the utility wares has diagonal incised lines on the rim itself opposite a vertical appliqued ridge (see Table 3).

Although not abundant, lip notched jars are a consistently occurring East Texas utility ware. Rim punctated jars in the 41AN28 utility ware assemblage have rows of either fingernail or tool punctations (see Table 3 ), but cane, circular, fingernail, linear, and tool punctated decorative elements likely also occur in rows or in random patterns of the bodies of utility ware vessels. 
The sherds from fine ware vessels at 41AN28 include engraved (94.3 percent), engraved-lip notched (1.4 percent), and red-slipped (4.3 percent) (Table 4). About 12 percent of the engraved sherds are from bottles, including one Hickory Engraved bottle with fine horizontal lines on the upper vessel body, a sherd from a Poynor Engraved bottle with a diagonal hatched zone (Figure 4f), and a bottle rim from a Hume Engraved vessel with hatched and cross-hatched diagonal zones (Figure 4a). None of the engraved or engraved-lip notched sherds have had a red or white pigment rubbed in the engraved lines.

Table 4. Decorative methods and elements in the fine ware sherds from 41AN28.

Decorative method/ Rim Body N

Decorative element

Engraved

cross-hatched diagonal zone and hatched

diagonal zone

curvilinear lines

curvilinear and diagonal lines

$1 \quad 7$

diagonal lines, L-R

1

8

diagonal lines, R-L

$\begin{array}{lll}1 & - & 1\end{array}$

diagonal opposed lines

$\begin{array}{lll}1 & - & 1\end{array}$

narrow diagonal hatched zone

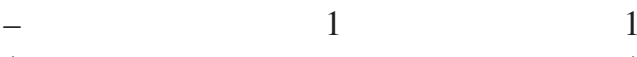

hatched triangle element

$-\quad 2$

horizontal lines

horizontal line and hatched triangle

$\begin{array}{lll}- & 8 & 8\end{array}$

horizontal line and narrow diagonal

$\begin{array}{lll}- & 3 & 3\end{array}$

hatched zone

horizontal line and hatched pendant triangles

horizontal and diagonal (R-L) lines

$\begin{array}{ll}- & 1\end{array}$

horizontal and diagonal lines and hatched triangle

horizontal and vertical lines and hatched triangles

$\begin{array}{lll}1 & - & 1 \\ 1 & - & 1 \\ - & 1 & 1 \\ 1 & 1 & 2\end{array}$

opposed lines

$\begin{array}{lll}- & 3 & 3\end{array}$

parallel lines

$\begin{array}{lrr}- & 18 & 18\end{array}$

rectilinear lines

straight line

$\begin{array}{ll}- & 1\end{array}$

1

$\begin{array}{lll}- & 11 & 11\end{array}$

\section{Engraved-Lip Notched}

horizontal line under lip and lip notched

1

\section{Red-Slipped}

ext. red-slipped

$\begin{array}{ll}- & 3\end{array}$

3

Totals

10

60

70

L-R: left to right; engraved lines begin at the left at the top of the rim and end at the right at the bottom of the rim $\mathrm{R}-\mathrm{L}=$ right to left; engraved lines begin at the right at the top of the rim and end at the left at the bottom of the rim 


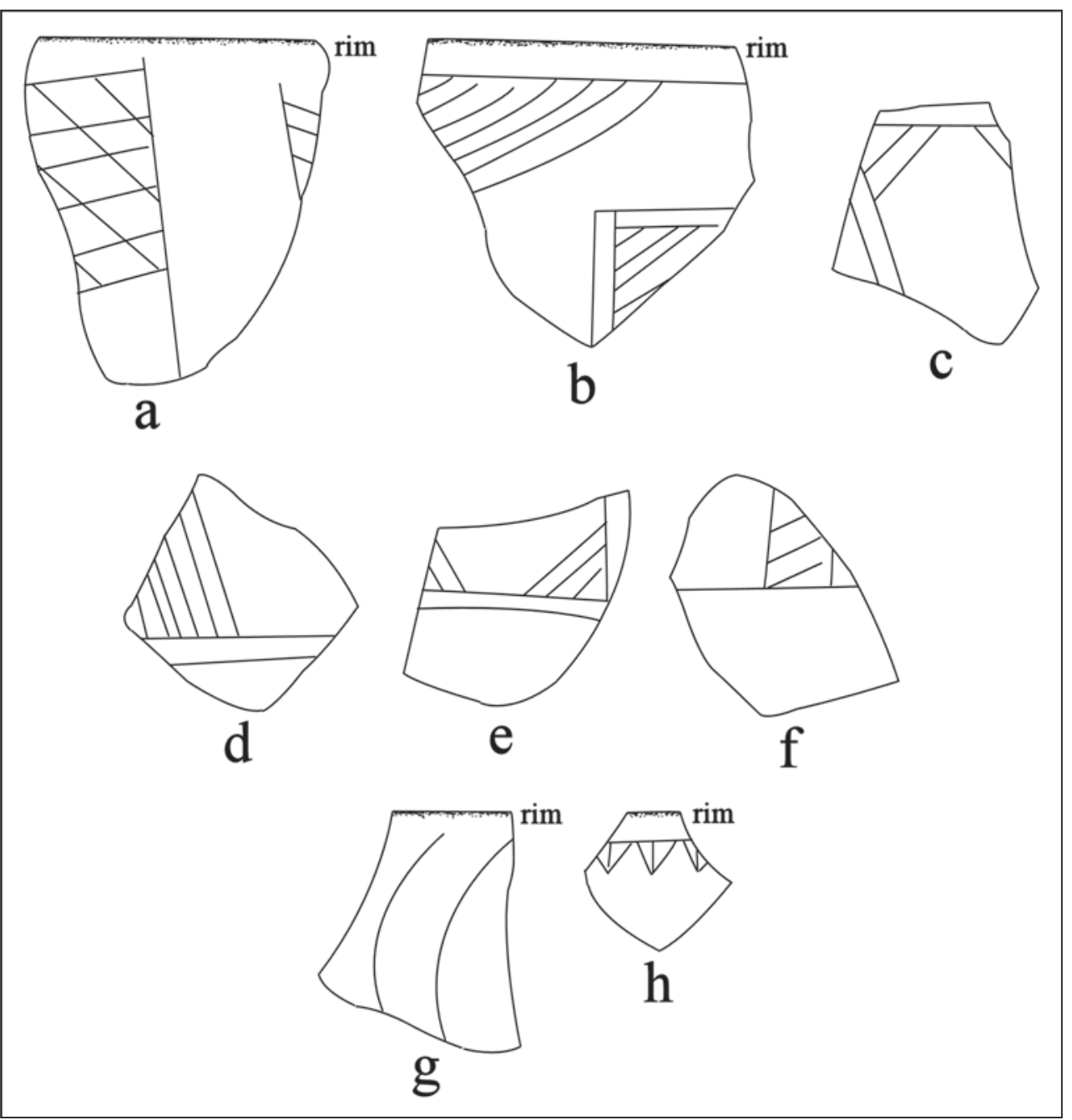

Figure 4. Selected decorative elements on fine ware sherds from 41AN28: a-b, g-h, rim sherds; c-f, body sherds.

Two of the fine ware rims from 41AN28 have diagonal engraved lines, and another has both curvilinear and diagonal lines; these rims have not been identified with specific ceramic types. A probable Poynor Engraved carinated bowl rim has horizontal and vertical lines and hatched triangles (see Figure 4b). Other Poynor Engraved sherds from upper Neches River basin defined varieties (Perttula 2011:Figure 6-65) have hatched triangles (Var. A, see Figure 4c), horizontal lines and hatched triangles (see Figure 4d, Var. $O$ or $Q$ ), var. Blackburn with horizontal lines and rectangular panels (see Figure 4e), continuous hatched triangles pendant from a horizontal engraved line (see Figure 4h, Var. C), and concentric semi-circles (Var. R, see Figure 4g). These varieties of Poynor Engraved occur in ca. A.D. 1400-1560 Frankston phase sites in the upper Neches (Perttula 2011:Table 6-37), although none of these varieties are the principal varieties of Poynor Engraved found on ancestral Caddo sites in the local upper river basin.

Other fine ware sherds from 41AN28 include a lip notched rim with a horizontal engraved line under the lip and three grog-tempered body sherds with an exterior red-slipped surface (see Table 4). These may be from Sanders Plain vessels.

A ceramic bird effigy head, probably from a Hood Engraved effigy bowl, was found in one of the plowed fields at 41AN28. Hood Engraved is a post-ca. A.D. 1400 vessel form in the upper Neches River basin (Perttula 2011:271), primarily found on sites dating between ca. A.D. 1400-1560. Hood Engraved, var. 
Hood - a vessel with an effigy head and broad horizontal engraved lines on the rim - is widely distributed in this region, occurring in burial and domestic contexts at a number of sites.

\section{Comparisons with sherds from the Pace McDonald Site}

Is 41AN28 contemporaneous with the Pace McDonald mound center that is located across Mound Prairie Creek from 41AN28? Perhaps 41AN28 represents a large habitation area that is associated with the Caddo construction and use of the mounds and the habitation areas in immediate proximity to the mounds that are believed to have occurred between cal. A.D. 1200-1410 (see Perttula et al. 2012)? A comparison of the character of the sherds from the fine ware and utility ware vessels from the two sites suggests that the sites are generally not contemporaneous, however, but that the Caddo occupations were sequent, with the principal Caddo component at 41AN28 dating after ca. A.D. 1400, likely during the early (sub-phase 1) to middle (sub-phase 2) temporal intervals of the Frankston phase of the Late Caddo period, while the Pace McDonald component dates to the Middle Caddo period.

The main differences between the decorated sherds from the two sites (Table 5) are as follows:

- fine wares are a good bit more common at the Pace McDonald site, particularly the proportion of sherds from red-slipped vessels (i.e., Sanders Plain) and the occurrence of Maxey Noded Redware; more than 11 percent of the decorated sherds from the Pace McDonald site are red-slipped compared to only 0.6 percent of the 41AN28 sherds;

- sherds from vessels with incised, tool punctated, and fingernail punctated decorations are much more common at Pace McDonald (58.4 percent) than they are at 41AN28 (28.1 percent);

- sherds with brushed decorative elements are 25 times more common at 41AN28 (48.8 percent) than they are at Pace McDonald (1.9 percent);

- and lastly, sherds from utility ware vessels are more common at 41AN28 (85.6 percent) than at Pace McDonald (73.4 percent).

Table 5. Summary of Decorated Sherds from the Pace McDonald site (41AN51) and 41AN28.

\begin{tabular}{lcccc}
\hline & \multicolumn{2}{c}{ Pace McDonald } & \multicolumn{2}{c}{ 41AN28 } \\
& No. & Percent & No. & Percent \\
\hline Engraved & 109 & 14.9 & 66 & 13.6 \\
Engraved-lip notched & - & - & 1 & 0.2 \\
Engraved-red-slipped & 3 & 0.4 & - & - \\
Red-slipped & 77 & $\underline{\mathbf{1 . 2}}$ & 3 & 0.6 \\
Red-slipped-appliqued & 1 & 0.1 & - & - \\
& & & & 14.4 \\
Sub-total, fine ware & 190 & $\underline{\mathbf{2 6 . 6}}$ & 70 & 18.2 \\
& & & & 7.0 \\
Incised & 205 & $\underline{\mathbf{2 9 . 9}}$ & 88 & 0.4 \\
Tool punctated & 136 & $\underline{\mathbf{1 9 . 8}}$ & 34 & 2.9 \\
Linear punctated & 7 & 1.0 & 2 & 0.8 \\
Fingernail punctated & 60 & $\underline{\mathbf{8 . 7}}$ & 14 & 0.2 \\
Circular punctated & 16 & 2.3 & 4 & - \\
Cane punctated & 1 & 0.1 & 1 & 5.2 \\
Pinched & 13 & 1.9 & - & 0.2 \\
Incised-punctated & 41 & 6.0 & 25 & 1
\end{tabular}


Table 5. Summary of Decorated Sherds from the Pace McDonald site (41AN51) and 41AN28, cont.

\begin{tabular}{lcccc}
\hline \multirow{2}{*}{ Decorative method } & \multicolumn{2}{c}{ Pace McDonald } & \multicolumn{2}{c}{ 41AN28 } \\
& No. & Percent & No. & Percent \\
\hline Appliqued & 3 & 0.4 & 1 & 0.2 \\
Appliqued-punctated & 1 & 0.1 & - & - \\
Brushed & 13 & 1.9 & 236 & $\underline{\mathbf{4 8 . 8}}$ \\
Brushed-incised & 1 & 0.1 & 4 & 0.8 \\
Brushed-incised- & 1 & 0.1 & 2 & 0.4 \\
$\quad$ punctated & - & - & 1 & 0.2 \\
Brushed-punctated & 498 & 73.4 & 414 & $\mathbf{8 5 . 6}$ \\
Sub-total, utility ware & 688 & 100.0 & 484 & 100.0 \\
\hline Totals & & & \\
\hline
\end{tabular}

Note: entries bold and underlined denote significant percentage differences between the two sites

Sherds from brushed utility ware vessels, particularly jars, are a distinctive characteristic of both Middle, Late, and Historic Caddo sites in much of East Texas. It also seems to be the case that the relative proportions of brushed utility wares increase through time in those areas where brushed vessels were made and used, such that sherds with brushing marks are particularly common (i.e., $>50$ percent of all decorated sherds) in many post-A.D. 1400 East Texas ceramic assemblages, such as at 41AN28. One of these areas is with the Late Caddo and Historic Caddo period ceramic assemblages in the upper and mid-Neches (Frankston and Allen phase sites) (Marceaux 2011; Perttula 2011:Table 6-38). In fact, 50.3 percent of the decorated sherds in a ca. A.D. 1400-1480 site at Lake Palestine in the upper Neches River basin are brushed (50.2 percent of the decorated sherds from 41AN28 have brushing marks), compared to 61.4-68.3 percent brushed in ca. A.D. 1480-1560 Frankston phase sites, and 75.8-80.0 percent brushed in ca. A.D. 1560-1650 Frankston phase sites; the proportion of brushed sherds increased in post-A.D. 1650 Allen phase sites.

Another indication of the differences in the ages of the Caddo components at 41AN28 and Pace McDonald is the occurrence of Poynor Engraved sherds in the former ceramic assemblage, and the absence of this fine ware type at Pace McDonald (Perttula et al. 2012:Tables 3, 14, and 21). The Pace McDonald engraved fine wares have hatched zones, pendant triangles, cross-hatched, and curvilinear elements, as well as simple straight and geometric elements. The 41AN28 engraved sherds have similar hatched triangle elements, hatched and cross-hatched zones, curvilinear and diagonal elements, as well as pendant triangles (see Table 4), but as discussed above, several of the rim and body sherds are from post-A.D. 1400 varieties of Poynor Engraved. Nevertheless, there does appear to be some evidence of stylistic continuity in the engraved decorative elements in the fine ware sherds from both sites, perhaps indicating that the temporal differences between the two sites are not substantial (i.e., generational rather than a scale of a century or more). Clearly, the sharing of decorative elements in both the fine wares and utility wares in the ceramic assemblages at both sites also suggests that they are part of the same ancestral Caddo ceramic tradition. Also indicative of a shared Caddo ceramic tradition, one where plain ware vessels were also an important part of the overall vessels in use by Mound Prairie Creek Caddo groups, is the similarity in plain to decorated sherd ratios between 41AN28 and Pace McDonald: 2.55-3.04. This ratio is considerably lower (i.e., $<1.50$ ) at contemporaneous Frankston phase sites on the upper Neches River (see Perttula 2011:Table 6-38).

Where the two ceramic assemblages are also similar is in the high proportion of sherds from vessels tempered with grog. More than 91 percent of the sherds from 41AN28 are from grog-tempered vessels compared to 86.3 of the sherds from the Pace McDonald site (Perttula et al. 2012:Table 28). The overall 
limited use of bone temper in the vessels made and used at both sites is indicative of the heavy use of grog temper for vessel manufacture in ancestral Caddo sites in the upper Neches River basin.

\section{Clay Pipes}

A small L-shaped elbow pipe was collected from the surface of one of the plowed fields at 41AN28 (Figure 5). The L-shaped form of elbow pipe appears to be the earliest elbow pipe form in the Neches River basin in East Texas, based on an examination of clay pipes from mortuary features (Perttula 2011). Based on available archaeological information from the upper Neches, such pipes were made from ca. A.D. 13201480. An L-shaped elbow pipe was recovered from the Pace McDonald site (Perttula et al. 2012:15 and Figure 5), across Mound Prairie Creek from 41AN28.

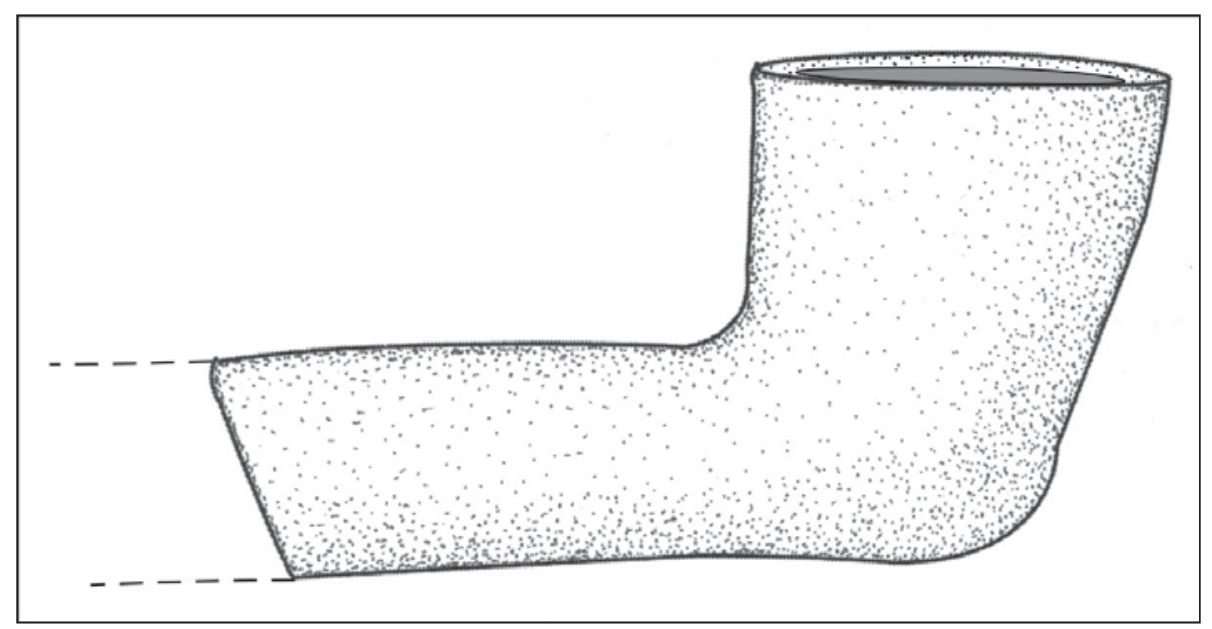

Figure 5. L-shaped elbow pipe fragment from a surface collection area at 41AN28.

Although not in the TARL collections from 41AN28, notes in the TARL files indicate that four elbow pipe sherds had been collected from the midden area. These were described as pipe stem sherds with horizontal incised lines around the stem. These sherds are likely from Var. B or Var. C pipes in the upper Neches River basin (Perttula 2011:Figure 6-23). Such pipes are estimated to date from ca. A.D. 1400-1560 to ca. A.D. 1400-1650, respectively (Perttula 2011:215).

Also from a surface collection is a grog-tempered long-stemmed Red River pipe bowl sherd. The bowl is $4.2 \mathrm{~mm}$ thick.

\section{SUMMARY AND CONCLUSIONS}

Site 41AN28 is a multi-component archaeological site on an alluvial terrace along the west side of Mound Prairie Creek in the upper Neches River basin. The Pace McDonald site (41AN51), a large Middle Caddo period mound center and village, is directly across from 41AN28 on the east side of the creek.

Surface collections in several plowed fields, as well as numerous small test pits in a midden deposit in one area of the site, were conducted by Clyde Amick, a local avocational archaeologist, between 1983-1985 at 41AN28. The site covers a ca. $1 \mathrm{~km}$ long area on the west side of Mound Prairie Creek, and it appears to have been marked by surface and shallow $(0-60 \mathrm{~cm})$ archaeological deposits with various kinds of ceramic and lithic artifacts. The temporally diagnostic projectile points found at the site indicate the landform was used by aboriginal peoples as early as ca. 10,000 years B.P., but with a more intensive use by peoples in the Late Archaic (ca. 5000-2500 years B.P.) and Woodland (ca. 2500-1200 years B.P.) periods; the Woodland 
period occupation is characterized by early arrow point forms as well as plain and decorated sandy paste ceramic sherds.

The principal use of 41AN28 was by ancestral Caddo peoples as a likely place of year-round habitation. The main Caddo component is marked by a midden deposit and surface scatters of plain and decorated ceramic sherds and ceramic pipe sherds. The ceramic assemblage includes sherds from plain, utility, and fine ware vessels that are tempered primarily with grog; less than 9 percent of the sherds from the site are from bone-tempered vessels. The analysis of the utility and fine ware sherds indicate that the main Caddo component at 41AN28 took place during the Late Caddo period Frankston phase-estimated to have occurred between ca. A.D. 1400-1560 - and the Caddo occupation there was not contemporaneous with the mound building and use/village occupation at the Pace McDonald site.

\section{ACKNOWLEDGMENTS}

I want to thank Jonathan Jarvis at the Texas Archeological Research Laboratory at The University of Texas at Austin for facilitating access to the collections and records from 41AN28. Lance Trask prepared the figures in this article.

\section{REFERENCES CITED}

Ellis, L. W.

2013 Woodland Ceramics in East Texas and a Case Study of Mill Creek Culture Ceramics. Bulletin of the Texas Archeological Society 84:137-180.

Marceaux, P. S.

2011 The Archaeology and Ethnohistory of the Hasinai Caddo: Material Culture and the Course of European Contact. Ph.D. dissertation, Department of Anthropology, The University of Texas at Austin.

Perttula, T. K.

2011 The Ceramic Artifacts from the Lang Pasture Site (41AN38) and the Place of the Site within an Upper Neches River Basin Caddo Ceramic Tradition. In Archeological Investigations at the Lang Pasture Site (41AN38) in the Upper Neches River Basin of East Texas, assembled and edited by T. K. Perttula, D. B. Kelley, and R. A. Ricklis, pp. 145-320. Archeological Studies Program Report No. 129, Texas Department of Transportation, Environmental Affairs Division, Austin.

2013 Caddo Ceramics in East Texas. Bulletin of the Texas Archeological Society 84:181-212.

Perttula, T. K., M. Walters, and B. Nelson

2012 Archeological Investigations at the Pace McDonald Site (41AN51): A Middle Caddo Mound Center in the Neches River Basin in East Texas. Special Publication No. 21. Friends of Northeast Texas Archaeology, Pittsburg and Austin.

Shafer, H. J. and M. Walters

2010 The Browning Site (41SM195A) Lithics: Considering Patterns of Identity and Interaction through Lithic Analysis. Bulletin of the Texas Archeological Society 81:127-151.

Suhm, D. A. and E. B. Jelks (editors)

1962 Handbook of Texas Archeology: Type Descriptions. Special Publication No. 1, Texas Archeological Society, and Bulletin No. 4, Texas Memorial Museum, Austin. Reprinted in 2009, Gustav's Library, Davenport, Iowa.

Turner, E. S., T. R. Hester, and R. L. McReynolds

2011 Stone Artifacts of Texas Indians. Third Edition. Taylor Trade Publishing, Lanham, Maryland. 